\title{
Effect of Corporate Governance Mechanisms on Value Relevance of EPS and BV: Evidence from the Indian Tourism Industry
}

\section{Saleem Ahmed Aqlan ${ }^{*}$, Yaser M. Alashaf ${ }^{2}$, Mohammed Salem Barakat ${ }^{3}$ and Dheya A. Zaid ${ }^{4}$}

${ }^{1}$ Research Scholar, Department of Commerce, Dr. Babasaheb Ambedkar Marathwada University, Aurangabad, Maharashtra 431001, India.

${ }^{2}$ Research Scholar, Department of Management, Dr. Babasaheb Ambedkar Marathwada University, Aurangabad, Maharashtra 431001, India.

${ }^{3}$ Assistant Professor, D.O/ Commerce University of Science and Technology, Yemen. ${ }^{4}$ Research Scholar, Department of Commerce, Aligarh Muslim University, India.

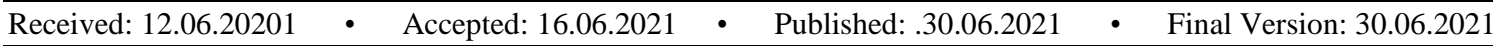

\begin{abstract}
The impact of corporate governance on the valuation of Earnings Per Share (EPS) and Book Value is investigated in this article (BV). Differently from previous empirical studies in the area of corporate governance and value relevance of EPS and BV, this study investigates this impact within a unique setting of publicly listed tourism firms Using panel data from a selection of some Bombay Stock Exchange (BSE) listed companies from 2013 to 2015. The paper explored three aspects of corporate governance mechanisms: the board of directors (composition, size and diligence), the audit committee (composition, size and diligence) and foreign ownership. The study uses descriptive statistics, correlation and a multi-regression model to analyses the influence of corporate governance on the value relevance of EPS and BV for the Indian tourism industry. The results show that the interaction between corporate governance mechanisms and value relevance of $\mathrm{BV}$ has more impact on the share prices than EPS. Therefore, it is recommended that the Indian tourism industry focuses on corporate governance mechanisms to improve its value relevance of $\mathrm{EPS}, \mathrm{BV}$, and share prices.
\end{abstract}

Keywords: corporate governance mechanisms, value relevance, earning per share, book value, tourism industry.

\section{Introduction}

The quality of financial reporting is a significant concern for both established and future investors (Chalaki, Didar, \& Riahinezhad, 2012). Several firms, such as Parmalat, WorldCom, Enron, etc., have been involved in accounting scams that have undermined investor trust in the consistency of financial reports and the management team. (Klai \& Omri, 2011). The Failure of financial disclosure created the need to increase executive supervision by developing a robust corporate governance framework and increasing the integrity of financial information. (Petra, 2007; Firth et al., 2007; Brown and Caylor, 2006; Beekes and Brown, 2006; Karamaou and Vafeas, 2005).

Various studies have been performed to examine the different dimensions of corporate governance (e.g., Al-Homaidi et. al, 2019a; Almaqtari, 2019; Almaqtari et .al, 2020a; Farhan et.al 2019; Hashed\& Almaqtari, 2021; Almaqtariet.al, 2020e)

\footnotetext{
* Corresponding Author: alashafco@gmail.com
} 
Despite the plenteous studies on the influence of corporate governance mechanisms on the quality of financial reporting in developed countries, there is little evidence about this topic in emerging markets, especially in India. This study investigates the influence of corporate governance on financial reporting quality in the context of India. Specifically, It empirically explores the impact of three corporate governance structures on financial reporting standards: the board of directors (composition, size and diligence), the audit committee (composition, size and diligence), and the audit quality mechanism. This study has employed four regression models from previous studies; Jones (1991), Dechow and Dichev (2002), McNichols (2002), and Collins and Kothari (1989) as proxies for the quality of financial reporting. In three ways, this study adds to current research. First, it discusses the effect of corporate governance on the quality of financial reporting in India, an emerging market. Second, it evaluates the proxies for financial reporting quality developed by other studies. Third, it assesses the financial reporting quality using both earning and accrual measures to provide an acceptable financial reporting quality measure for the Indian background. This paper is structured as follows; next, the literature review and development of hypotheses are discussed in the section. The research method is defined in section three. Results and interpretation are presented in section four, and guidelines and limitations are finalized in section five.

\section{Literature review}

One of the most critical tasks of corporate governance is to ensure the financial reporting quality process (Cohen, Krisnamoorthy and Wright, 2004). Several authors reported a relationship between some attributes of corporate governance and good quality of financial reporting. For example, Jiang et al. (2008) found that poor corporate governance is correlated with earning leadership to achieve analyst forecasts. Likewise, Fairuz (2009) concluded that there is a correlation between the low quality of financial reporting and poor corporate governance after regulating the impact of the political factor. The study also found that the link between the quality of financial reporting and the influence of political factors is mediated by corporate governance.

Several previous studies have looked into corporate governance in India (e.g., Almaqtari et al.,2020b; Almaqtari et al.2020b; Almaqtari et al.,2021;Almaqtari et al.,2020d; Farhan et al.2021a;Farhan et al.2021b;Farhan et al.2020)

Further, Bonetti, Magnan, \& Parbonetti (2016) investigated the influence of firm and country-level governance on the quality of financial reporting in 14 European countries. They indicated that company and country-level governance are complementary to each other. Hence, countries characterized by a strong compliance, strong board-level monitoring firms demonstrate a higher level of financial reporting efficiency than weak board-level monitoring firms. Similarly, weak enforcement countries and strong board-level monitoring firms appear to increase the quality of financial reporting. (Almaqtari et al. 2021) suggested that there is no supporting evidence that the collective influence of corporate governance mechanisms has shifted from Saudi GAAP to IFRS to become more influential. The impact and relationship of the quality of financial reporting and corporate governance have been investigated in many countries and from different aspects. In Tunisia, Kali and Omri (2011) analysed Tunisian companies' financial reporting and corporate governance efficiency. They found that the quality of financial information is affected by governance mechanisms. More Specifically, the power block holders, foreigners, and families reduce the quality of financial reporting. Contradictory, the control by financial institutions and the State is linked with a good financial disclosure quality. In Iran, Kardan, Salehi, \& Abdollahi (2016) noted that, based on the qualitative aspects of the Iranian Financial Accounting Standards Board's theoretical principles, 
a positive relationship exists between debt financing and the quality of financial reporting. However, a negative relationship is observed between debt financing and Centred on the Dechow and Dichev quality of financial reporting (2002) model. In Australia, Cheung, Evans, \& Wright (2013) concluded that significance, reliability, comparability, and understandability could capture the notion of "quality". But in China, Habib \& Jiang (2015) observed an opaque environment of financial reporting in China.

(Aqlan, S. A et al. 2020) reported that the size of the total board had a positive and substantial effect on return on assets, return on employed capital, benefit after tax identification and return on net worth. More specifically and concerning the relationship of the board of directors as one important mechanism of corporate governance with financial reporting quality, Chalaki, Didar \& Riahinezhad (2012) and Chalaki et al., (2012) found that there is no relationship between the quality of financial reporting and some characteristics of corporate governance such as board size and independence, institutional and ownership concentration and there is no observed evidence to support a significant relationship between the quality of financial reporting from one side and audit size, firm size and firm age from the other side. Consistently, a large board size was found to reduce the content of incomes information and increase the earnings management of American firms (Vafeas, 2000), Singaporean firms (Ahmed et al., 2006) and New Zealandia firms (Bradbury et al., 2006). Tan, Xue, $\& \mathrm{Yu}$ (2013) found that the proposals led to improved financial reporting quality passed relating to executive compensation and board of directors, especially for firms with lower financial reporting quality before voting.

In the context of the audit committee as one important corporate governance mechanisms, Chandar, Chang, \& Zheng (2012) observed that firms that have a higher quality of financial reporting are associated with overlapping compensation and audit committees than those without overlapping compensation and audit committees. Similarly, Zheng (2008) The U-Shaped relationship between the quality of the financial reports and the magnitude of the audit committee is reversed.. Further, Baxter (2007) concluded that financial reporting quality improved in the year of audit committees formation and the earnings quality was significantly reduced measured using the modified Jones (1991) model. However, a comparison of the modified Jones (1991) model and Dechow and Dichev (2002), it is revealed that audit committees are effective at mitigating earnings management using a model of Dechow and Dichev (2002). But generally, the study found no significant association between the financial reporting quality and the audit committees' characteristics. (Almaqtari et al. 2020) reported that some firms also have several variations from regulation requirements on corporate governance.

Almaqtari et al. (2021) found that other corporate governance mechanisms have a lower impact on IFRS compliance and financial reporting quality than audit committee attributes.

In addition, Jensen and Meckling (1976) and Watts and Zimmerman (1983) argue that external audit can guarantee the integrity and accuracy of financial reports and serve as an efficient control mechanism for controlling management behaviours. It is commonly believed that organisations choose their audit quality standards when hiring

an auditor. (Beisland et al., 2013). In the sense of this article, auditor preference refers to the choice between external auditors of the name brand (Big Four) compared to non-Big Four external auditors. (Alabede 2012; Beisland, et al. 2013; Soliman and Elsalam 2012). The Big Four, a multinational accounting and professional services firm, performs the vast majority of audits for publicly listed 
entities and several private companies. (Chin, 2008). However, four large firms, generally referred to as "the big four," control the auditing industry. Among those firms are Deloitte, Ernst and Young (EY), PricewaterhouseCooper (PWC), Touché and Tohmatsu (DTT) and Klynveld Peat Marwick Goerdeler (KPMG). The big four work in over 140 counties, and each has more than 140,000 employees with total global revenue of $\$ 103.61$ billion in 2011 (Alabede, 2012). The value importance of accounting information varies between Big 4 and non- Big 4 auditors, with businesses audited by Big 4 auditors having more value than Big 4 auditors. (Alali \& Foote, 2012) Since enhanced audit quality is associated with improved accounting earnings quality (Chen et al., 2001).

Based on the review of literature discussed above and the objective outlined for this study; the hypotheses can be framed as follows:

H01: There is no significant impact of corporate governance on the quality of financial reporting of some Indian listed companies.

H02: There are no significant differences in the impact of corporate governance on the quality of financial reporting between companies audited by Big 4 from other companies audited by Non-Big 4

\section{Research design}

\section{3-1. Measuring of Depending Variable}

There is no universally accepted metric for measuring the quality of financial reporting. Therefore, different proxies for financial reporting quality were utilised in previous studies. For example, Baxter (2007) and Li \& Wang (2010) used Jones (1991), Baxter (2007), Li \& Wang (2010) and Kardan et al. (2016) employed Dechow and Dichev (2002). Further, Fairuz (2009), Chalaki et al. (2012), and Klai \& Omri (2011) employed McNichols (2002). Also, Klai \& Omri (2011), Chalaki et al. (2012) used Collins and Kothari's 1989 models as proxies for financial reporting quality.

This study measures the quality of financial reporting using four proxies. The first model is the McNichols (2002) model, which uses the standard deviation of the residuals or error terms to assess reporting quality. Large values for the model residuals indicate a high level of discretionary accruals and, as a result, poor financial information quality. The model equation is as follows:

$\frac{T C A_{j, t}}{\operatorname{ASSET}_{j, t}}=\beta_{0 j}+\beta_{1, j} \frac{C F O_{j, t-1}}{A S S E T_{j, t}}+\beta_{2 j} \frac{C F O_{j, t}}{\operatorname{ASSET}_{j, t}}+\beta_{3 j} \frac{\mathrm{CFO}_{j, t+1}}{\operatorname{ASSET}_{j, t}}+\beta_{4 j} \frac{\Delta R E V_{j, t}}{\operatorname{ASSET}_{j, t}}+\beta_{5 j} \frac{P P E_{j, t}}{\operatorname{ASSET}_{j, t}}+\varepsilon_{j, t}$

Where; $T C A j$, Firm $\mathrm{j}$ is total current accruals in year t, CFit: Current-period operating cash flows, CFit-1: previous-period operating cash flows, CFit+1: next-period operating cash flows, ?? REVit: sales adjustment and PPEit: land, plant, and equipment stage. All of these variables are scaled by total lagged assets (TAit-1)

The second model captures the revenue information content of Collins and Kothari (1989). A high level of the standard deviation of the residuals indicates low information quality. As follows, the model equation is:

$$
R E T_{i t=} a_{0}+a_{1} E A R N_{i t}+a_{2} \Delta E A R N_{i t}+a_{3} N E G_{i t}+a_{4} E A R N * N E G_{i t}+\varepsilon_{i t}
$$

Where RETit: the current year's annual stock returns, EARNit: the current year's net income per share, EARNit: the variation in earnings per share between 't-1' and ' $t$ ' year, NEGit: a binary variable 
equivalent to 1 if the company makes a loss and 0 otherwise and EARNit*NEGit: the relationship between the earnings per share and their sign.

The third one is the earnings quality proxy utilised is based on Jones' model (1991). This model calculates the discretionary per cent of total accruals, which is then used as a management metric for earnings. To compensate for changes in the firm's economic status and partition total accruals into discretionary and non-discretionary components, Jones (1991) used the following expectations model for total accruals:

$$
\frac{\operatorname{TACC}_{i, t}}{A S S E T_{i, t-1}}=\alpha_{1} \frac{1}{A S S E T_{i, t-1}}+\alpha_{2} \frac{\Delta R E V_{i, t}}{A S S E T_{i, t-1}}+\alpha_{3} \frac{P P E_{i, t}}{A S S E T_{i, t-1}}+\varepsilon_{i t}
$$

Where: Tai, $\mathrm{t}=$ Total accruals in year $\mathrm{t}$ for the firm I; Ait- $1=$ Total assets in year $\mathrm{t}-1$ for the firm I; $\triangle \mathrm{REV}$ it $=$ Revenues in year $\mathrm{t}$ less revenues in year $\mathrm{t}-1$ for the firm I; PPEit $=$ Gross property, plant and equipment in year $\mathrm{t}$ for the firm $\mathrm{I} ; \varepsilon \mathrm{\varepsilon}, \mathrm{t}=$ Error term in year $\mathrm{t}$ for firm $\mathrm{i}$.

Dechow and Dichev, the fourth model (2002). Dechow, Sloan, and Sweeney (1995) showed that models of discretionary accruals usually produced low power tests of economically plausible magnitudes for earnings management. Therefore, an alternative model was also used to build proxies for earnings efficiency to try to address the critiques of the updated Jones model.

$$
\Delta W C_{t=} a_{0}+\mathrm{b}_{0}+\mathrm{b}_{1} C F O_{t-1}+\mathrm{b}_{2} C F O_{t}+\mathrm{b}_{3} C F O_{t+1}+\varepsilon_{t}
$$

Where: $\Delta \mathrm{WCt}=\Delta$ Working capital in year t i.e. $\Delta$ Accounts receivable $+\Delta$ Inventory $-\Delta$ Accounts payable $-\Delta$ Taxes payable $+\Delta$ Other assets (net); CFOt- $1=$ Cash flows from operations in year $\mathrm{t}-1$; $\mathrm{CFOt}=$ Cash flows from operations in year $\mathrm{t} ; \mathrm{CFO} t+1=$ Cash flows from operations year in year $\mathrm{t}+$ 1. The residuals capture the degree to which accruals map into cash flow realisations in past, present, and future cash flows from the equation: Dechow and Dichev (2002) measure accruals and profits quality at the corporate level., they employed the standard deviation of the residuals from their time series model. A higher residual standard deviation denotes a poorer match between accruals and cash flows, thus lowering quality accruals and earnings (Dechow and Dichev 2002). The poorer the quality of accruals and earnings, the larger the residual for each sample company, and vice versa.

\section{3-2. Measurement of independent variables}

Some attributes have been analyzed concerning corporate governance mechanisms, such as board independence, the board size, and board diligence. Further, independence of audit committee, audit committee size, the diligence of audit committee, and big 4 have been taken as important attributes and measures of corporate governance mechanisms. The following table (1) summarizes the measurement of the independent variables and the operational definition of the study: 
Table 1. Measurements of the independent variables

\section{Indenendent Variables}

Board of Directors Effectiveness

\begin{tabular}{lll}
\hline Size & BSZE & Total No. of the members of B.O.D \\
\hline Independence & BIND & No. of Independent members / total No. of members \\
\hline Diligence & BDLG & $\begin{array}{l}\text { Total No. of meetings attended by all board members/ } \\
\text { total No. of meetings held during the year }\end{array}$ \\
\hline
\end{tabular}

Audit Committee Effectiveness

Size ACSZE Total No. of the members of AC

Independence

ACIND

No. of Independent members / total No. of members

Diligence

ACDLG

Total No. of meetings attended by all AC members/ total

No. of meetings held during the year

\section{$\underline{\text { Audit Quality }}$}

Big. 4 AQB4 1 if the company audited by a big 4 or 0 otherwise

\section{Denendent Variables}

Financial Reporting Quality

\section{3-3. Model Specification}

A multiple regression analysis was used to measure the impact of corporate governance mechanisms on financial reporting quality. The following multiple regressions were constructed to investigate the relative contribution of each corporate governance trait in affecting financial reporting quality. To investigate the effects of corporate governance measures on FRQ, the study suggests the following model:

$$
\begin{aligned}
& \text { FRQit }=a 0+a 1 \text { BSIZEit }+a 2 \text { BCOMPit }+a 3 B D E L i t+a 4 A C S I Z E i t+a 5 \text { ACCOMPit }+ \\
& a 6 A C D E L i t+a 7 \text { AQit }+ \text { cit }
\end{aligned}
$$

\subsection{Sample}

The study aims to study the effect of corporate governance mechanisms on the quality of financial reporting of selected listed Indian companies. A selection of 30 companies listed on the Bombay Stock Exchange (BSE) by market capitalisation was randomly selected from the top 100 companies. This analysis is based on secondary data collected from published annual reports from 2012 to 2016 of the listed companies. In addition, market prices for the company's shares were derived from the BSE website. 


\section{4- Empirical results and analysis}

\subsection{Descriptive Statistics}

Table 2 presents descriptive statistics for the study variables, including the minimum and maximum values of the variables, mean, and standard deviation. The size of the board of

directors shows a minimum value of 4 members in the board against 25 as a maximum member in the board, with a mean of 11.28 and S.D of 2.77.Also, The independence of the board has a minimum value of 0.21 against 0.78 as a maximum value with a mean of .52 and high S.D which is 0.11 . This indicates that board independence in some companies is less than $25 \%$, and the number of independent members in the board is less than $25 \%$. Similarly, board diligence has a minimum value of 0.44 and a maximum value of 0.98 with a mean of

0.81 And S.D of 0.11, which indicates that the attendance of the board members in some companies is less than 50\%. Regarding the audit committee, the minimum number of members is 2 with minimum 0.38 independent members and 0.33 as the minimum value for attendance. The maximum number of Audit committee members is 8 , with maximum independence of $100 \%$ and maximum attendance of 0.97. The mean of audit quality is 0.34 with S.D of 0.47 . The other value of FRQCK, FRQMCN, FRQJON, and FRQDD are based on standardized residuals.

Table 2. Descriptive Statistics

\begin{tabular}{|c|c|c|c|c|c|}
\hline & $\mathrm{N}$ & Minimum & Maximum & Mean & $\begin{array}{c}\text { Std. } \\
\text { Deviation }\end{array}$ \\
\hline Board Size & 155 & 4.00 & 25.00 & 11.2774 & 2.76935 \\
\hline Board composition & 155 & .21 & .78 & .5227 & 10790 \\
\hline Board Diligence & 155 & .44 & .98 & .8078 & .10517 \\
\hline Audit committee Size & 155 & 2.00 & 8.00 & 3.9226 & 1.00347 \\
\hline $\begin{array}{l}\text { Audit committee } \\
\text { Composition }\end{array}$ & 155 & .38 & 1.00 & .8709 & 14793 \\
\hline $\begin{array}{l}\text { Audit committee } \\
\text { Diligence }\end{array}$ & 155 & .33 & 97 & .8163 & 14777 \\
\hline Audit Quality & 155 & 0 & 1 & .34 & 474 \\
\hline $\begin{array}{l}\text { FRQDDP } \\
\text { FRQJOP }\end{array}$ & $\begin{array}{l}155 \\
155\end{array}$ & $\begin{array}{l}-7.19 \\
-7.81\end{array}$ & $\begin{array}{l}2.86 \\
6.25\end{array}$ & $\begin{array}{r}.0000 \\
-.0267\end{array}$ & $\begin{array}{l}.99021 \\
.98448\end{array}$ \\
\hline FRQMNCP & 155 & -4.67 & 6.10 & .0000 & .98363 \\
\hline FRQCKP & 155 & -4.40 & 1.63 & .0000 & .99021 \\
\hline FRQP & 155 & -3.08 & 2.66 & -.0067 & .59486 \\
\hline
\end{tabular}

"FRQDD is the absolute value of residuals of Dechow and Dichev (2002) model, FRQJO is the absolute value of residuals of Jones (1991) model, FRQMCN is the absolute value of residuals of McNichols (2002) model, and FRQCK is the absolute value of residuals of Collins and Kothari (1989) model. FRQ is the aggregate of the summary measurement of FRQ computed as the standardised average of the four FRQ proxies." 


\subsection{Correlation:}

Table 3 provides the Pearson correlation matrix. Among all independent variables, only board diligence shows high correlation with financial reporting quality. FRQ proxies, FRQ measured by MC Nicholas models, have the highest value (0.788) of correlation with FRQ against (0.39) for FRQ measured by Collions and Kaothari model. The other two proxies of FRQ; FRQDD and FRQJO have values of (0.61) and (0.62), respectively. Because the correlations between the independent variables are low, collinearity is unlikely to be a problem in our investigation.

Table 3. Pearson correlation matrix

\begin{tabular}{|c|c|c|c|c|c|c|c|c|c|c|c|}
\hline Variables & ACCOM & ACDEL & ACSIZE & BCOM & BDEL & BSIZE & BV & EPS & FO & P & SIZE \\
\hline ACCOM & & & & & & & & & & & \\
\hline ACDEL & 0.20 & 1.00 & & & & & & & & & \\
\hline ACSIZE & -0.38 & -0.51 & 1.00 & & & & & & & & \\
\hline BCOM & 0.28 & 0.11 & -0.24 & 1.00 & & & & & & & \\
\hline BDEL & -0.27 & 0.08 & 0.10 & 0.00 & 1.00 & & & & & & \\
\hline BSIZE & 0.04 & -0.16 & 0.48 & -0.16 & -0.10 & 1.00 & & & & & \\
\hline BV & 0.07 & 0.10 & -0.05 & 0.01 & -0.03 & 0.01 & 1.00 & & & & \\
\hline EPS & 0.21 & 0.18 & 0.00 & -0.05 & 0.03 & 0.11 & 0.35 & 1.00 & & & \\
\hline FO & -0.01 & -0.04 & 0.00 & 0.02 & -0.10 & 0.09 & 0.36 & 0.02 & 1.00 & & \\
\hline P & 0.15 & 0.04 & 0.10 & -0.08 & 0.01 & 0.14 & 0.47 & 0.67 & 0.10 & 1.00 & \\
\hline SIZE & -0.05 & -0.07 & 0.21 & 0.08 & -0.08 & 0.49 & 0.06 & -0.14 & 0.03 & 0.01 & 1.00 \\
\hline
\end{tabular}

\subsection{Regression Results}

Table 4 displays the equation regression results (5). The value of the adjusted R2 is 0.11 , suggesting that corporate governance structures contribute about 11 percent to the variability of financial reporting efficiency, including board composition, the board size, board diligence, audit committee composition, audit committee size, audit committee diligence, and audit quality.

Table 4. Model Summary

\begin{tabular}{ccccc}
\hline & & & Adjusted R & Std. Error of the \\
Model & $\mathrm{R}$ & $\mathrm{R}$ Square & Square & Estimate \\
1 & $.397^{\mathrm{a}}$ & .158 & .106 & .56254
\end{tabular}


a. Predictors: (Constant), Total Sales/ Revenues, Board Diligence, Audit committee Diligence, Board composition, Audit committee Size, Audit Quality, Total Assets, Audit committee Composition, Board Size

Table 5. Regression results

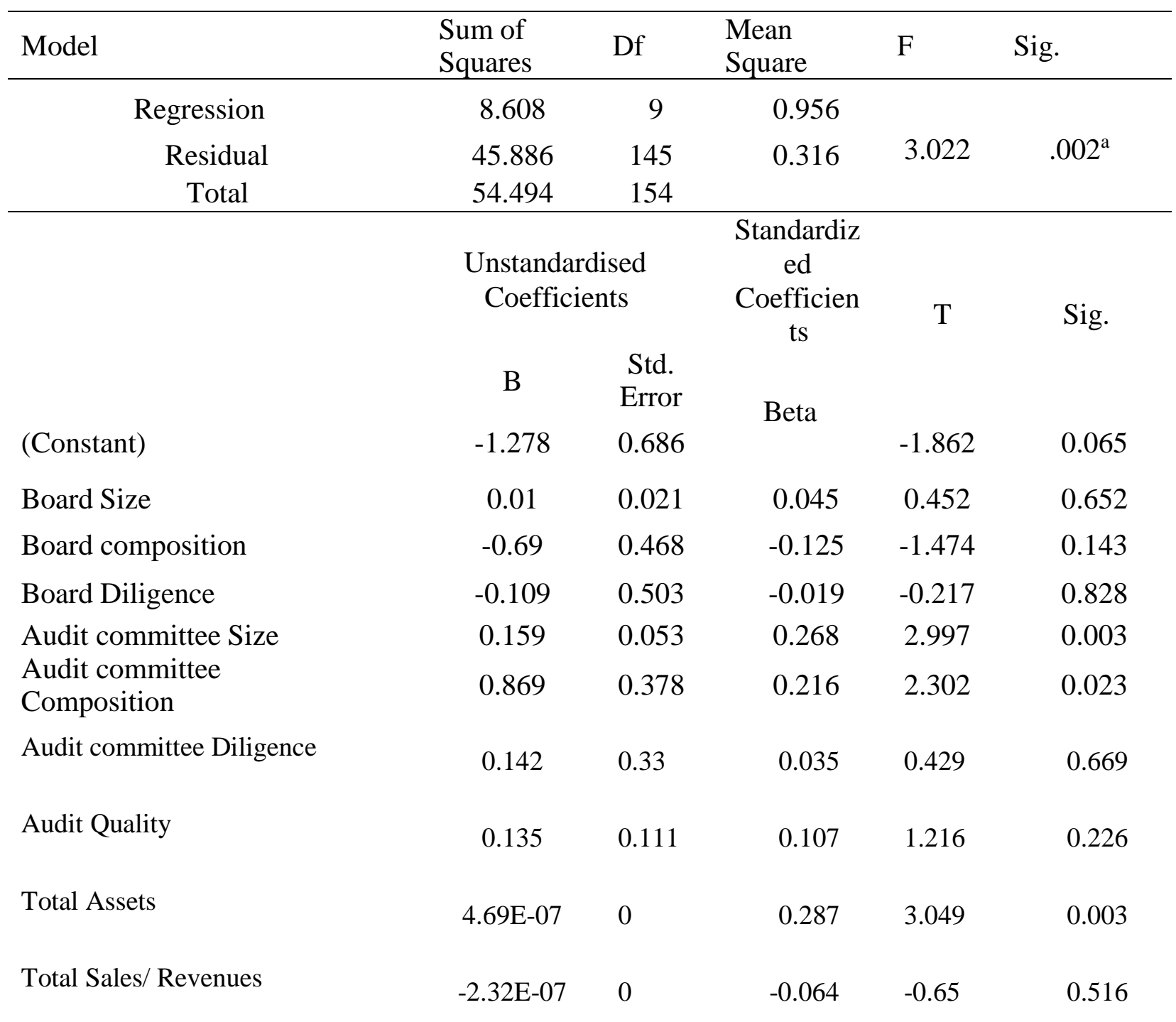

Table (5) shows the variances and coefficients that indicate that the regression model fits with a significance value of less than .05; (0.002). The dependent variable is FRQ measured by the aggregate measure of the four above proxies (FRQDD, FRQMC, FRQJand FRQCK). Further, among corporate governance mechanisms investigated by this study, onlyaudit committee size and composition significantly impact the quality of financial reporting, with a significance level of 0.003 and 0.023 , respectively which are less than 0.05 significance level. 
Table 6. Independent sample t-test

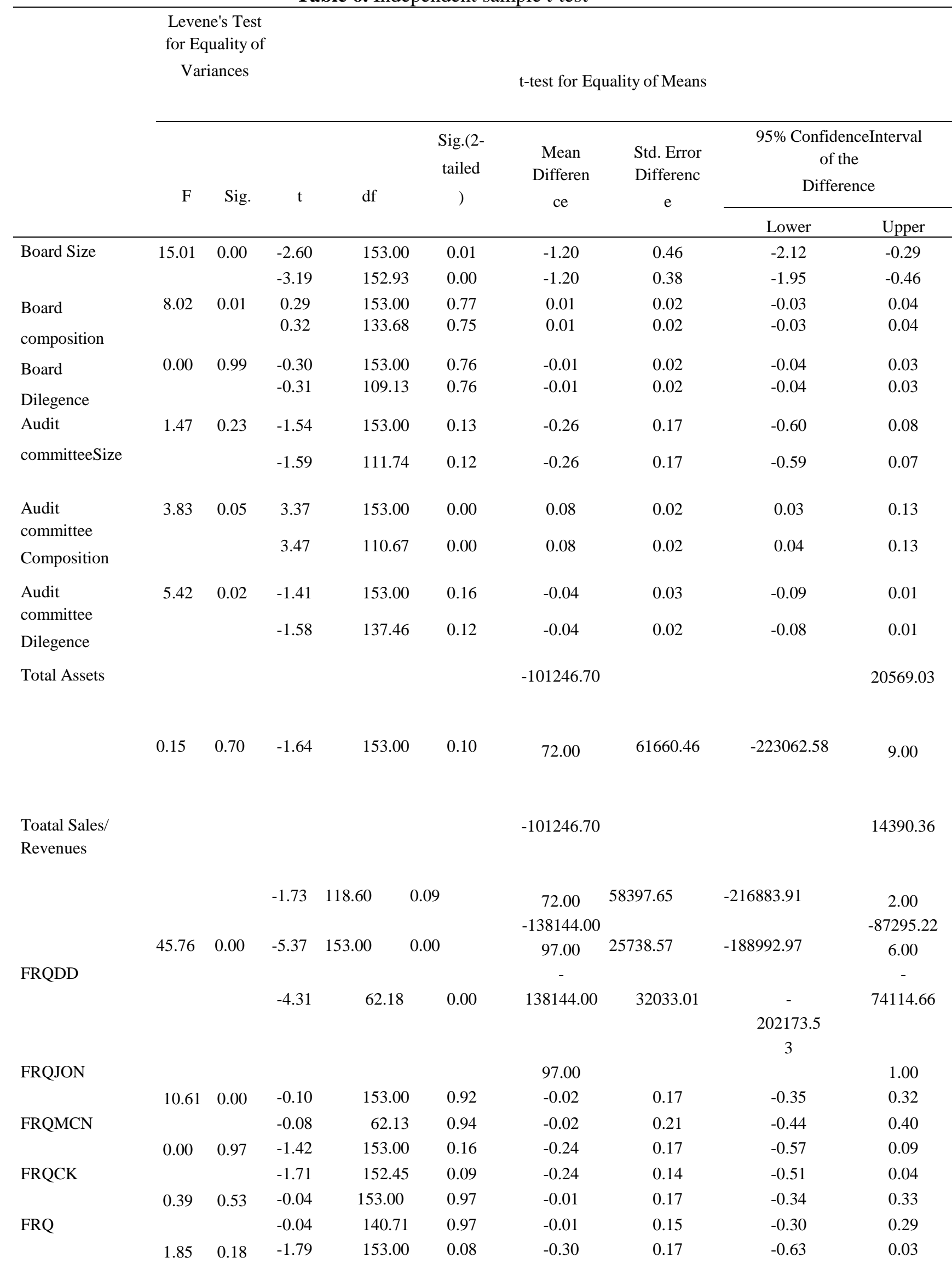


Table ( 6 ) shows the independent sample $t$ test. It presents comparisons of means based on the audit quality. Audit quality was considered a dummy variable of 1 if the company was audited by a big 4 or 0 otherwise. Accordingly, All variables and proxies splitted into two groups according to the dummy variable of the audit quality. The independent-sample $t$ test results indicate significant differences in board composition, the board size, and audit committee diligence between companies audited by big4 and Non-big 4. But, the results reveal that there is no significant differences between companies audited by big 4 and Non-big 4 in financial reporting quality measured by the aggregate measure. This leads the study to accept the Null hypothesis (H02).

\section{Conclusion, Recommendation, and Direction for Future Research.}

The impact of corporate governance mechanisms on India's quality of financial reporting was examined in this paper. Three aspects of corporate governance mechanisms were discussed in the study: board of directors (composition, size, and diligence), audit committee (composition, size, and diligence), and audit quality on the quality of financial reporting.. It employed secondary data of a sample of 30 listed companies from 2012 up to 2016. The study used four regression models from previous studies; Jones (1991), Dechow and Dichev (2002), McNichols (2002), and Collins and Kothari (1989) as proxies for financial reporting quality. The study found that corporate governance mechanisms contribute about 0.11 of the variability of the financial reporting quality. Among corporate governance mechanisms, only audit committee size and composition significantly impact financial reporting quality. Further, the study results revealed no significant difference in the impact of corporate governance mechanisms on FRQ in terms of companies audited by Big 4 or Non-Big4. It is recommended that models of financial reporting quality need to be developed, and corporate governance should be revised to improve its financial reporting quality and avoid earning management or any future scandals. This research is likely to have some limitations - the research sample and the time limit. The sample and the number of years an increase in future studies.

\section{References}

[1] Ahmed, K., Hossain, M. \& Adams, M. (2006). The Effects of Board Composition and Board Size on the Informativeness of Annual Accounting Earnings. Corporate Governance: An International Review, 14, (5), 418-431.

[2] Baxter, P. J. (2007). Audit committees and financial reporting quality (Doctoral dissertation, University of Southern Queensland).

[3] Becker, Connie L., DeFond, Mark L., Jiambalvo, James, Subramanyam, K.R., 1998. The effect of audit quality on earnings management. Contemporary Accounting Research 15, 1-24.

[4] Beeks, W. \& Brown, P.(2006). Better- governed australian firms make more informative disclosures. journal of business finance and accounting, 33(3), 422-450.

[5] Becker, C., DeFond, M., Jiambalvo, J. \& Subramanyam, K. (1998). The Effect of Audit Quality on Earnings Management. Contemporary Accounting Research, 15, 1-24.

[6] Bonetti, P., Magnan, M., \& Parbonetti, A. (2016). The influence of country- and firm- level governance on financial reporting quality : revisiting the evidence. journal of business finance \& accounting, 1-49.

[7] Bradbury, M., Mak, Y. \& Tan, s. (2006). Board characteristics, audit committee characteristics and abnormal accruals. pacific accounting review, 18, 47-68.

[8] Brown, J., Falaschetti, D. \& Orlando, M. (2010). Auditor Independence and Earnings Quality: Evidence for Market Discipline vs. Sarbanes-Oxley Proscriptions. American Law and Economics Review, 12, (1), 39-68. 
[9] Brown, L. \& Caylor, M. (2006). Corporate governance and firm valuation. journal of accounting and public policy, 25(4), 409-434.

[10] Chalaki, P., Didar, H., \& Riahinezhad, M. (2012). Corporate governance attributes and financial reporting quality : empirical evidence from iran. International Journal of Business and Social Science, 3(15), 223229.

[11] Chandar, N., Chang, H., \& Zheng, X. (2012). Does overlapping membership on audit and compensation committees improve a firm 's financial reporting quality? review of accounting and finance, 11(2), 141165 doi 10.1108/14757701211228192. http://doi.org/10.1108/14757701211228192

[12] Cheung, E., Evans, E., \& Wright, S. (2013). An historical review of quality in financial reporting in australia. Pacific Accounting Review, $22(2$ doi 10.1108/01140581011074520), 147-169. http://doi.org/10.1108/01140581011074520

[13] Chung, R., Firth, M. \& Kim, J. (2003). Auditor Conservatism and Reported Earnings. Accounting Business Research, 33, 19-32.

[14] Collins, d. \& kothari, s. (1989). An analysis of intertemporal and cross-sectional determinants of earnings response coefficients. journal of accounting and economics, 11, 143-181.

[15] Cohen, J., Krishnamorthy, G. \& Wright, A. (2004). The corporate governance mosaic and financial reporting quality. Journal of Accounting Literature, 23, 87-152.

[16] DeAngelo, L. E. (1981).Auditor size and audit quality. Journal of Accounting and Economics, 3(3), 183199.

[17] Dechow, P. \& Dichev, I. (2002). The quality of accruals and earnings: the role of accrual estimation errors. the accounting review, 77, 35-59 (supplement).

[18] Dimitropoulos, P. \& Asteriou, D. (2010). The effect of board composition on the informativeness and quality of annual earnings: empirical evidence from greece, research in international business and finance, 24, 190-205.

[19] Fairuz, M. (2009). Political influence, corporate governance and financial reporting quality: evidence from companies in malaysia.

[20] Firth, M., Fung, P. \& Rui, O. (2007). Ownership, two-tier board structure, and the informativeness of earnings- evidence from china. journal of accounting and public policy, 26 (4), 463-496.

[21] Habib, A., \& Jiang, H. (2015). Corporate governance and financial reporting quality in china: a survey of recent evidence. "Journal of International Accounting, Auditing and Taxation," 24, $29-45$. http://doi.org/10.1016/j.intaccaudtax.2014.12.002

[22] Jensen , M . and Meckling , W . ( 1976 ) Theory of the fi rm: managerial behavior, agency costs and ownership structure . journal of financial eco- nomics 3 (3) : $305-360$.

[23] Jiang, G. H. and Wang, H. S. (2008), 'Should Earnings Thresholds be Used as Delisting Criteria in Stock Market?', Journal of Accounting and Public Policy, 27: 409-19.

[24] Johl, S. K., Johl, S. K., Subramaniam, N., \& Cooper, B. (2013). Internal audit function , board quality and financial reporting quality : evidence from malaysia. Managerial Auditing Journal, 28(9), 780-814-6-2013886. http://doi.org/10.1108/maj-06-2013-0886

[25] Aqlan, S. A., Lahane, R. B., Farhan, N. H., Aswale, S., \& Lengare, K. B. (2020). Board characteristics and banks profitability: empirical evidence from India. Studies in Economics and Business Relations, 1(1), 920. https://doi.org/10.48185/sebr.v1i1.73

[26] Jones, J. (1991), "Earnings management during import relief investigation", Journal of Accounting Research .29.193-228.

[27] Karamanou, I. \& Vafeas, N. (2005), "The association between corporate boards, audit committees, andmanagement earnings forecasts: an empirical analysis", Journal of Accounting Research, 43, (3), 453486.

[28] Kardan, B., Salehi, M., \& Abdollahi, R. (2016). The relationship between the outside financing and the quality of financial reporting : Evidence from iran. Journal of Asia Business Studies, 10(1), 20-40-4-201427. http://doi.org/10.1108/jabs-04-2014-0027

[29] Klai, N., \& Omri, A. (2011). Corporate governance and financial reporting quality : the case of tunisian firms. International Business Research, 4(1), 158-166. 
[30] Li, q., \& Wang, T. (2010). Financial reporting quality and corporate investment efficiency: chinese experience, 1(2), 197-213. http://doi.org/10.1108/20408741011052591

[31] Mcnichols, M.F. (2002), "Discussion of the quality of accruals and earnings: the role of accrual estimation errors", The Accounting Review, vol. 77 no. 1, pp. 61-69.

[32] Petra, S. (2007), "The effects of corporate governance on the informativeness of earnings. economics of governance", 8, 129-152.

[33] Teoh, S. \& Wong T. (1993). Perceived Auditor Quality and the Earnings Response Coefficients. The Accounting Review, 68, 346-367.

[34] Vafeas, N. (2000). Board structure and the informativeness of earnings. Journal of Accounting and Public policy, 19(2), 139-160.

[35] Watts, R. and Zimmerman, L. (1983), "Agency problems, auditing and the theory of the firm: some evidence", Journal of Law \& Economics, Vol. 14, pp. 311-68.

[36] Almaqtari, Faozi A., Mohd Shamim, Hamood Mohd Al-Hattami, and Saleem Ahmed Aqlan. "Corporate governance in India and some selected Gulf countries." International Journal of Managerial and Financial Accounting 12, no. 2 (2020): 165-185.

[37] Zheng, X. (2008). An empirical analysis of the relationship between audit committee multiple directorships and financial reporting quality.

[38] Almaqtari, F. A., Hashed, A. A., \& Shamim, M. Impact of corporate governance mechanism on IFRS adoption: A comparative study of Saudi Arabia, Oman, and the United Arab Emirates. Heliyon, 7(1), e05848.

[39] Al-Homaidi, E. A., Almaqtari, F. A., Ahmad, A., \& Tabash, M. I. (2019a). Impact of corporate governance mechanisms on financial performance of hotel companies: Empirical evidence from India. African Journal of Hospitality, Tourism and Leisure, 8(2), 1-21. http//: www.ajhtl.com

[40] Almaqtari, F. (2019). Impact of Corporate Governance on IFRS Adoption: A Comparative Study of India and some Selected Gulf Countries (Doctoral dissertation, Aligarh Muslim University).

[41] Almaqtari, F. A., Al-Hattami, H. M., Al-Nuzaili, K. M., \& Al-Bukhrani, M. A. (2020a). Corporate governance in India: A systematic review and synthesis for future research. Cogent Business \& Management, 7(1), 1-32. https://doi.org/10.1080/23311975.2020.1803579

[42] Almaqtari, F. A., Farhan, N. H., Al-Homaidi, E. A., \& Mishra, N. (2020b). An empirical evaluation of financial reporting quality of the Indian GAAP and Indian accounting standards. International Journal of Accounting, Auditing and Performance Evaluation, 16(2-3), 200-229. https://doi.org/10.1504/IJAAPE.2020.112717

[43] Almaqtari, F. A., Farhan, N. H., Yahya, A. T., \& Al-Homaidi, E. A. (2020c). Macro and socio-economic determinants of firms' financial performance: empirical evidence from Indian states. International Journal of Business Excellence, 21(4), 488-512. https://doi.org/10.1504/IJBEX.2020.108556

[44] Almaqtari, F. A., Hashed, A. A., \& Shamim, M. (2021). Impact of corporate governance mechanism on IFRS adoption: A comparative study of Saudi Arabia, Oman, and the United Arab Emirates. Heliyon, 7(1), 1-26. https://doi.org/10.1016/j.heliyon.2020.e05848

[45] Almaqtari, F. A., Hashed, A. A., Shamim, M., \& Al-ahdal, W. M. (2021). Impact of corporate governance mechanisms on financial reporting quality: a study of Indian GAAP and Indian Accounting Standards. Problems and Perspectives in Management, 18(4), 1.

[46] Almaqtari, F. A., Hashid, A., Farhan, N. H., Tabash, M. I., \& Al-ahdal, W. M. (2020d). An empirical examination of the impact of country-level corporate governance on profitability of Indian banks. International Journal of Finance \& Economics. A head of print. https://doi.org/10.1002/ijfe.2250

[47] Almaqtari, F. A., Shamim, M., Al-Hattami, H. M., \& Aqlan, S. A. (2020e). Corporate governance in India and some selected Gulf countries. International Journal of Managerial and Financial Accounting, 12(2), 165-185. https://doi.org/10.1504/IJMFA.2020.109135

[48] Farhan, N. H., Alhomidi, E., Almaqtari, F. A., \& Tabash, M. I. (2019). Does Corporate Governance Moderate the Relationship between Liquidity Ratios and Financial Performance? Evidence from Indian Pharmaceutical Companies. Academic Journal of Interdisciplinary Studies, 8(3), 144-144. http://www.richtmann.org/journal/index.php/ajis/article/view/10570 
[49] Farhan, N. H., Almaqtari, F. A., Al-Homaidi, E. A., \& Tabash, M. I. (2021a). Board of directors' composition, cash conversion cycle and firms' performance: empirical evidence from India. International Journal of Sustainable Economy, 13(2), 197-218. https://doi.org/10.1504/IJSE.2021.114614

[50] Farhan, N. H., Almaqtari, F. A., Al-Matari, E. M., Senan, N. A. M., Alahdal, W. M., \& Hazaea, S. A. (2021b). Working Capital Management Policies in Indian Listed Firms: A State-Wise Analysis. Sustainability, 13(8), 1-25. https://doi.org/10.3390/su13084516

[51] Farhan, N., Tabash, M., Almaqtari, F., \& Yahya, A. (2020). Board composition and firms' profitability: Empirical evidence from pharmaceutical industry in India. Journal of International Studies, 13(3), 180-194. doi:10.14254/2071-8330.2020/13-3/12

[52] Hashed, A., \& Almaqtari, F. (2021). The impact of corporate governance mechanisms and IFRS on earning management in Saudi Arabia. Accounting, 7(1), 207-224.10.5267 /j.ac.2020.9.015 